\title{
Performance of Papaya Varieties for Growth Parameters under Northern Dry Zone of Karnataka, India
}

\author{
Tulasigeri Gunnannavar*, D.P. Prakash, Kulapati Hipparagi, D. Satish, \\ Kantesh Gandolkar, B.S. Sagar and Shivayogi Ryavalad
}

\author{
Department of Fruit science, Bagalkot, College of Horticulture Bagalkot, University of \\ Horticultural Sciences Bagalkot, 587-104 (Karnataka), India \\ *Corresponding author
}

\section{A B S T R A C T}

\begin{tabular}{|l|}
\hline Ke y w o r d s \\
Varieties, Growth \\
and dry zone. \\
\hline Article Info \\
\hline Accepted: \\
23 August 2017 \\
Available Online: \\
10 September 2017 \\
\hline
\end{tabular}

Identification and use of region specific varieties or cultivars would certainly improve sustainable growth, yield and economic returns. To know the performance of papaya varieties for growth parameters under northern dry Zone was carried out during May 2015 to January 2016 at Haveli, Bagalkot (Fruit orchard), University of Horticultural Sciences, Bagalkot, with 6 papaya varieties. The highest plant height $(146.15 \mathrm{~cm})$, number of leaves (29.50), number of flowers (172.07) average number of flowers per plant (103.11) and average number of fruits per plant (25.71) was recorded in the variety Amrita. The maximum plant girth $(41.39 \mathrm{~cm})$, early flowering (72.64 days), early fruit formation (79.79 days), early fruit harvesting (134.54 days) and the minimum crop duration (214.34 days) was recorded in the variety Red Lady. The highest internodal length in the genotype Coorg Honey Dew $(7.29 \mathrm{~cm})$ and the maximum number of fruit sin the genotype Vinayaka (36.31). Among the six varieties Amrita and Coorg Honey Dew were found to be superior over other varieties.

\section{Introduction}

Papaya (Carica papaya L.) belongs to the family Caricaceae and is one of the most economically important fruit crops of the tropical and subtropical regions of the world. It is a dicotyledonous, polygamous and diploid species with geographical origin being Southern Mexico and Costa Rica. Papaya is basically a tropical fruit, which can be grown successfully in subtropical conditions also. Most of the papaya growing regions lie between $30^{\circ} \mathrm{N}$ to $45^{\circ} \mathrm{S}$ latitude of the equator. It grows best at an altitude of 1000$2000 \mathrm{~m}$ above the mean sea level with a mean temperature of $28-38^{\circ} \mathrm{C}$.
India leads the world in papaya production and occupies an area about 114.97 thousand hectares, with annual production of $4912 \mathrm{MT}$ and productivity of tonnes and $42.30 \mathrm{t} \mathrm{ha}^{-1}$ respectively (NHB, 2015).

Papaya is a backyard tropical fruit crop, nowa-days it is one of the commercially grown fruits throughout the world.

It has become commercially important fruit crop due to evolving high yielding varieties through crop improvement programme which generates more income for farmers. 
Papaya is highly cross pollinated crop. It is having different sex expressions such as monoecious, dioecious and gynodioecious. Usually, gynodioecious varieties are preferred for production as there is more number of perfect flowers on plant and does not need care by the growers towards maintenance of male and female plant ratio as in case of monoecious and dioecious varieties. Now-adays climatic conditions are varying a lot from region to region. The adverse climatic conditions such as high or low temperature and humidity, variation in day to day temperature and humidity causes severe crop losses due to reduced vegetative growth, delay in flowering, flower and fruit drop, improper fruit development, reduction in quality of fruit in papaya (Jana et al., 2010; Meena et al., 2012; Singh et al., 2010).

The growers, of late, are facing one or the other problem that limits the full expression of its growth and productivity. In the recent past, the commercial production is hampered by various biotic and abiotic factors.

One of such problems is the Papaya Ring Spot disease, a major viral disease caused by Papaya Ring Spot Virus (PRSV) transmitted by aphids and posed threat to farmers and papaya industries. The virus affects the plants mainly depends on genotype of plant which can be visually seen by chlorotic degradation, stunted growth, leaf malformation and subsequent reduction in fruit yield. The yield reduction due to Papaya Ring Spot Virus is reported to be $50-80 \%$. The notability and frequency of this problem is found to be related to agro climatic zone of the country from the plant system owing to its unique physiological plasticity.

Further, most of the area under commercial production of papaya in India is occupied by one or two cultivars. Though, a few local/ state specific varieties such as Coorg Honey
Dew in Karnataka and Ranchi in Bihar are in cultivation, they are not widely accepted varieties in the other regions of the country. Moreover, such local varieties grown are monoecious/dioecious in nature, poor in yield, quality and physico-chemical properties and does not fetch good price in market (Meena et al., 2012; Balamohan et al., 2010).India having varied agro climatic conditions and there is lack of studies related to evaluation of newly developed varieties to find out suitability of such varieties to varied agroclimatic conditions. Also, just selecting a suitable variety for a particular agroclimatic region will lessen the burden of crop management by farmer to a greatest extent to get high optimum yield. Because of this evaluating different varieties of papaya suitable for different agro climatic conditions should take front seat for recommending varieties suitable for different agroclimatic regions. However, no such study has been noticed related to evaluation of papaya varieties under northern dry zone of Karnataka. In this view, the present study has planned to evaluate certain recently released papaya varieties for growth parameter under northern dry zone of Karnataka.

\section{Silent features of varieties}

\section{Red lady}

The gynodioecious variety developed by known you seed company and it bears many oblong and oval shaped fruits measuring 6-20 (inch) in length. The fruit skin isamber in colour and pulp is deep red/pink in colour.

\section{Arka Surya}

This variety developed by Dr. M. R. Dinesh in the year 2005 by crossing Sunrise solo into Pink Flesh. The fruits are medium sized pear shape weighing about 600-800 gram with good keeping quality. 


\section{Arka Prabhat}

This variety also developed by Dr. M. R. Dinesh in the year 2005 by crossing Surya into Tainung-1 and the progeny was again cross with Local dwarf. The semi dwarf hybrid start to bearing at height of $(60-70 \mathrm{~cm})$ from ground level. The fruits are cylindrical in shape and medium size weighing about 900-1200 grams.

\section{Vinayaka}

This hybrid developed by VNR Seed Company. The dwarf hybrid starts to bearing $30(\mathrm{~cm})$ above ground level and these are high fruit weight about $2-3 \mathrm{~kg}$. The plant height ranges about $100-120 \mathrm{~cm}$. It is late but heavy bearing capacity about 30-35 fruits per plant and gives fruit yield is $165 \mathrm{t} / \mathrm{ha}$ (Anon, 2015). Individual fruit pulp thickness ranges from 2 $3 \mathrm{~cm}$ and having medium TSS about 8-9 ( $\left.{ }^{\mathrm{B}} \mathrm{Briks}\right)$. The plants mainly bear female flowers compared to hermaphrodites and produces round shape fruits.

\section{Coorg Honey Dew}

The gynodioecious variety is selection from Honey Dew and it bears medium sizes fruit weighing 1.5- $2 \mathrm{~kg}$. The fruits are dark in colour having ridges on surface. The fruits from hermaphrodite tree are elongated and oval; from female it is ovoid in shape.

The fruit yield $70 \mathrm{~kg}$ per plant. Popularly known as 'Madhubindu' and is cultivated for table as well as processing purpose.

\section{Amrita}

This hybrid developed by VNR seed company. The dwarf hybrid start to bearing $50(\mathrm{~cm})$ above ground level and these fruits are large sized having oblong shape weighing 800-900 gram. The fruits have oblong shape and yellow colour on surface. The fruit yield is $65 \mathrm{t}$ / ha (Anon, 2015). The plant height is ranges from $12-150 \mathrm{~cm}$ and bears fruit on $65 \mathrm{~cm}$ above the ground level. The fruits are small size and weighting about 800-1000gm. The TSS content and shelf life of fruit was very low compared to other varieties.

\section{Materials and Methods}

A field experiment on "Evaluation of papaya varieties for growth parameters under northern dry zone of Karnataka" was carried out during May 2015 to January 2016 at Haveli, Bagalkot (Fruit orchard), University of Horticultural Sciences, Bagalkot, with 6 papaya varieties. The details of the material used and the methods adopted during the course of the investigation are enumerated in this chapter. Bagalkot is located in Northern Dry Zone (Zone-3) of Karnataka State at $16^{0} 10^{1}$ North latitude, $75^{0} 42^{1}$ East longitudes and at an altitude of $542.0 \mathrm{~m}$ above the mean sea level.

\section{Nursery management}

The seeds were treated with $\mathrm{GA}_{3}$ with concentration of $200 \mathrm{ppm}$ along with $2 \%$ Potassium nitrate. The seeds were sown at a rate of one to two seeds per polythene bag of the size $20 \times 12 \mathrm{~cm}$ which is filled with a mixture of red earth, sand, farmyard manure and coco peat in 1:1:1:1 ratio. The bags were kept under polyhouse and irrigated at regular intervals. The seeds germinated within nine to sixteen days.

\section{Cultural practices}

The pits of $90 \mathrm{~cm}^{3}$ were dug out at a spacing $1.8 \times 1.8 \mathrm{~m}$ and filled with a mixture of $5 \mathrm{~kg}$ of FYM as a common dose for all the treatments. Seedlings of 45 days old were transplanted and the plots were kept free from weeds by regular hand mechanical weeding. Irrigation schedule was followed according to the requirements. 


\section{Treatment details}

One variety was considered as a treatment and each treatment was replicated four times. There were 12 plants marked in replication of which four plants were randomly selected for recording the observations. The experiment was laid out in Randomized Complete Block Design (RCBD).

$\mathrm{T}_{1}$ : Red Lady, $\mathrm{T}_{2}$ : Arka Surya, $\mathrm{T}_{3}$ : Arka Prabhat, $\mathrm{T}_{4}$ : Vinayaka, $\mathrm{T}_{5}$ : Coorg Honey Dew, $\mathrm{T}_{6}$ : Amrita

The observations on vegetative growth parameters like plant height, plant girth, number of leaves per plant, number of flower per plant, number of fruits per plant and internodal length observation were recorded at every month after transplanting. The plant height was measured in centimeter from ground to base of the newly emerged leaf.

The stem girth was measured in centimetre at $10 \mathrm{~cm}$ above from ground level with help of measuring tape, the number of leaves (fully open) was counted on the labelled plant and average was worked out at monthly interval days after transplanting and total leaf during life span was calculated, internodal length between the two petioles distance from $5^{\text {th }}$ petiole to $10^{\text {th }}$ petiole was recorded by using measuring scale. The length between average 5 to 10 petioles of the tagged plants was recorded and expressed in centimeter, number of days from transplanting to emergence of first flower was recorded and then average was worked out, fully opened flowers were counted from the tip to the base of the tree at monthly interval on the tagged plants by visual counting and expressed in number per plant, number of fruits was counted from the tip to the base of the tree at monthly interval on the tagged plants by visual counting and expressed in number per plant, The number of days required from planting to fruit set (duration in days) was recorded, When the first fruit started to ripe with yellow color beak the fruit count was made from the first fruit to the youngest fruit.

\section{Results and Discussion}

At $180^{\text {th }}$ day, the maximum plant height was recorded in the variety Amrita $(146.15 \mathrm{~cm})$ and the minimum was in Vinayaka (112.23 $\mathrm{cm}$ ) at 180 DAP (Table 1). This might be due to its genetical characters and due to it vigorous growth. Similar findings were obtained by Chalak et al., (2016). Kumar et al., (2015) found that plant height was ranges from 120 to $185.33 \mathrm{~cm}$. Das and Dinesh et al., (2014) observed that the highest plant height was observed in Sunrise Solo $(237.77 \mathrm{~cm})$ and the lowest was observed in Pusa Dwarf $(139.47 \mathrm{~cm})$.

Table 1 depicts the maximum plant girth was recorded in the variety Red Lady $(41.39 \mathrm{~cm})$ and the minimum was in Coorg Honey Dew $(34.31 \mathrm{~cm})$ at 180 DAP. From the observation, it is clear that if the plants with thick stem are selected they will have good plant spread with big sized fruits. However, it is to be borne in mind that higher plant spread will reduce the number of plants per unit area. Hence, selection for trees with medium sized or stem diameter with less spread is desirable Das (2001).These results are in confirmity with Meena et al., (2012). Das and Dinesh (2014) recorded that plant girth was maximum in cv. Sunrise solo $(37.77 \mathrm{~cm})$ and minimum observed in Pusa Dwarf $(29.23 \mathrm{~cm})$ variety.

The maximum number of leaves was recorded in the variety Amrita (29.50) at 180 DAP and the minimum was in Arka Surya (15.68) at 180 DAP the (Table 1). This might be due to its genetical character. These results were in accordance with Anh et al., (2011) observed that number leaves ranges from 17.6 to 21.8. 
The maximum intermodal length was noticed in variety Arka Surya $(8.76 \mathrm{~cm})$ and minimum was in variety Vinayaka $(5.92 \mathrm{~cm})$ at 90 DAP the (Table 1). The intermodal length decides the height of the plant and fruit bearing height. Variety had less intermodal length distance the plant height and first bearing height also less. These results are in line with Lim and Hawa (2007) internode length was found to be positively associated with tree height $(r=0.75)$. Similarly, number of nodes to first flower was positively correlated to earliness in flowering $(r=0.54)$ with lower number of nodes indicating earlier flowering. Similar findings were obtained by Pastors et al., (2010).

At $180^{\text {th }}$ day, the maximum number of flowers (172.07) was recorded in genotype Amrita and minimum was recorded in genotype Coorg Honey Dew (58.69) at 180 DAP (Table 1). This might be due to the genetical characters. Similar findings were found in Dias et al., (2011) and Pastors et al., (2010).

Table 1 depicts the maximum number of fruits was recorded in variety Vinayaka (36.31) and the minimum was found in variety Coorg Honey Dew (13.59). The variations in yield attributes of papaya might be due to various physiological phenomenon, viz. photosynthetic efficiency, rate of translocation of photosynthates from source to sink and photo-respiration that took place in the plant body and different genetic constitution of varieties, which are responsible for expression of genetic characters under a particular set of environment. Moreover, yield performance of any variety is considered as a cumulative effect of yield attributes. These results are in accordance with the findings of Meena et al., (2012). Similar findings were recorded byJana et al., (2010), Anh et al., (2011), Dias et al., (2011) and Tyagi et al., (2015).

Table.1 Performance of papaya varieties in respect to growth parameters

\begin{tabular}{|c|c|c|c|c|c|c|}
\hline \multirow[b]{2}{*}{ Treatment } & \multicolumn{6}{|c|}{ Growth parameters } \\
\hline & $\begin{array}{c}\text { Plant } \\
\text { height } \\
(\mathrm{cm})\end{array}$ & $\begin{array}{l}\text { Plant } \\
\text { girth } \\
(\mathrm{cm})\end{array}$ & $\begin{array}{c}\text { Internodal } \\
\text { length }\end{array}$ & $\begin{array}{l}\text { No of } \\
\text { leaves }\end{array}$ & $\begin{array}{c}\text { Number } \\
\text { of } \\
\text { flowers }\end{array}$ & $\begin{array}{l}\text { Number } \\
\text { of fruits }\end{array}$ \\
\hline T1- Red Lady & 140.22 & 41.39 & 5.53 & 29.00 & 92.40 & 31.50 \\
\hline T2- Arka Surya & 133.05 & 38.68 & 5.02 & 15.68 & 115.00 & 23.00 \\
\hline T3-ArkaPrabhat & 107.51 & 35.18 & 4.12 & 19.06 & 69.56 & 23.11 \\
\hline T4- Vinayaka & 112.23 & 35.64 & 5.04 & 24.00 & 108.96 & 36.31 \\
\hline T5- Coorg Honey Dew & 116.53 & 34.31 & 7.29 & 21.14 & 58.69 & 13.59 \\
\hline T6- Amrita & 146.15 & 40.86 & 4.93 & 29.50 & 172.07 & 34.50 \\
\hline S.Em. \pm & 4.61 & 1.36 & 0.21 & 1.03 & 4.54 & 1.28 \\
\hline CD@ @ $5 \%$ & 13.88 & 4.09 & 0.65 & 3.11 & 13.69 & 3.86 \\
\hline
\end{tabular}


Table. 2 Performance of papaya varieties in respect of average flowers and fruits

\begin{tabular}{|l|c|c|}
\hline \multicolumn{1}{|c|}{ Treatment } & Average number of flowers & Average number of fruit \\
\hline T1- Red Lady & 56.96 & 23.12 \\
\hline T2- Arka Surya & 63.82 & 18.10 \\
\hline T3- ArkaPrabhat & 43.52 & 17.81 \\
\hline T4- Vinayaka & 54.77 & 22.62 \\
\hline T5- Coorg Honey Dew & 32.89 & 13.27 \\
\hline T6- Amrita & 103.11 & 25.71 \\
\hline S.Em. \pm & 2.20 & 1.05 \\
\hline CD @ 5\% & 6.62 & 3.16 \\
\hline
\end{tabular}

Table.3 Performance of papaya varieties in respect of plant duration

\begin{tabular}{|l|c|c|c|c|}
\hline \multicolumn{1}{|c|}{ Treatment } & $\begin{array}{c}\text { Days taken for } \\
\text { first flowering }\end{array}$ & $\begin{array}{c}\text { No. of days } \\
\text { taken for fruit } \\
\text { formation }\end{array}$ & $\begin{array}{c}\text { No. of days taken } \\
\text { from fruit set to } \\
\text { harvesting }\end{array}$ & $\begin{array}{c}\text { Plant } \\
\text { duration } \\
\text { (days) }\end{array}$ \\
\hline T1- Red Lady & 72.64 & 79.79 & 134.54 & 214.34 \\
\hline T2- Arka Surya & 87.36 & 95.84 & 155.03 & 250.93 \\
\hline T3- ArkaPrabhat & 82.17 & 90.95 & 165.10 & 255.93 \\
\hline T4- Vinayaka & 97.38 & 105.05 & 145.53 & 250.89 \\
\hline T5- Coorg Honey Dew & 92.31 & 100.34 & 149.21 & 249.09 \\
\hline T6- Amrita & 103.08 & 111.58 & 168.58 & 280.43 \\
\hline \multicolumn{1}{|c|}{ S.Em. \pm} & 5.19 & 3.99 & 5.92 & 9.79 \\
\hline CD $(0.05)$ & 15.65 & 12.02 & 17.86 & 29.50 \\
\hline
\end{tabular}

Table 2 depicts the maximum average number of flowers was found in variety Amrita (103.11) and the minimum was found in variety Coorg Honey Dew (32.89).

This might be due to the genetical characters. These results are in contrast with Dias et al., (2011) and Pastors et al., (2010).

Among the varieties, the maximum average number of fruits was recorded in variety Amrita (25.71) and the minimum was found in the variety Coorg Honey Dew (13.27). This might be due to the genetical characters. These results were in accordance with Chalak et al., (2016), Kumar et al., (2015), Meena et al., (2012) and Jana et al., (2010).

Table 3 depicts the minimum days taken for first flowering was recorded in Red Lady (72.64 days) and maximum days to flowering were recorded in Amrita (103.08 days). This might due to the genetical characters. These results were in close confirmation with results obtained by Chalak et al., (2016), Kumar et al., (2015) and Prakash et al., (2015).

Red Lady recorded the minimum days taken for first fruit set (79.79 days) and the maximum in variety Amrita (111.58 days) (Table 3). This might due to the genetical characters. Similar finding was found bySingh et al., (2010).

The minimum days taken for fruit harvest after fruit set was recorded in variety Red Lady (134.54 days) and the maximum (168.58 days) number of days taken for fruit formation was in Amrita (Table 3). This might be due to the genetical characters. These results are in contrast with Das and Dinesh (2014). 
Table 3 depicts the minimum days taken for crop duration were recorded in variety Red Lady (214.34 days) and maximum found in variety Amrita (280.43days). This might be due to its earliest flowering and harvesting time helps in reducing the duration of the plant.

\section{References}

Anh, N. T., Trang, P. N., Hong, N. T. B. and Hoan, N. G., 2011. Evaluating agronomic characteristics of twelve local papaya (Carica papaya L.) varieties in Vietnam. Bull. Inst. Trop. Agr., 34: 15-22.

Anon, 2015. Indian Horticulture Database2015.http: //www. Nhb. gov.in.

Balamohan, T.N., Kumar, N., Soorianathasundaram, K., Auxcilia, J. and Cynthia, B., 2010. Evolving red pulp dioecious papaya. Acta Hort., 85: 89-92.

Chalak, S. U., Kamble, A. B. and Bhalekar, S. G., 2016. Evaluation of different papaya cultivars for yield, quality and papaya ring spot disease under pune conditions. J Krishi Vigyan, 5 (1): 60-63.

Das, S. C., and Dinesh, M. R., 2014. Studies on fruit set and germination in some papaya cultivars. Acta Hort., 1022: 8790.

Dias, N. L. P., Oliveira, E. J. D. and Dantas, J. L. L., 2011. Evaluation of papaya genotypes using agronomic descriptors and estimation of genetic parameters. Pesq. agropec. Bras., 46 (11): 14711479.

Jana, B. R., Rai, M., Nath, V. and Das, B.,
2010. Promising papaya (Carica papaya L.) varieties for Subtropical Plateau Region of Eastern India. Acta Hort., 851: 131-136.

Kumar, M., Prasad, Y., Kumar, M., Prakash, S. and Kumar, S., 2015. Evaluation of genetic variability, genetic advance, heritability and character association for yield and its contributing traits in papaya (Carica papaya L.).Society Plant Research, 28 (2): 99-102

Meena, B.S., Varma, L.R. and Mehta, R.S., 2012. Evaluation of papaya varieties under North Gujarat conditions. Indian J. Hort., 69 (1): 114-116.

Pastor, M. C. R., Rodrigo, M. G. L. and Sanchez, M. L. S., 2010. Behavior of papaya cultivars Sunset, Sunrise and genotypes of 'Baixinho De Santa Amalia' and BH - 65 in the South of Tenerife Island. Rev.Bras.Frutic., Jaboticabal-SP., 32 (4): 1105-1115.

Prakash, J., Singh, K., Goswami, A. K. and Singh, A. K., 2015. Comparison of plant growth, yield, fruit quality and biotic stress incidence in papaya var. PusaNanha under polyhouse and open field conditions. Indian J. Hort., 72 (2): 183-186.

Singh, D. B., Roshan, R. K., Pebam, N. and Yadav, M. 2010. Effect of different spacings on growth, yield and yield characters of papaya (Carica papaya L.) cv. Coorg Honey Dew. Acta Hort., 851: 291-294.

Tyagi, M., Singh, H. and Jawandha, S. K., 2015. Performance of papaya cultivars grown under protected conditions. Indian J. Hort., 72 (3): 334-337.

\section{How to cite this article:}

Tulasigeri Gunnannavar, D.P. Prakash, Kulapati Hipparagi, D. Satish, Kantesh Gandolkar, B. S. Sagar and Shivayogi Ryavalad. 2017. Performance of Papaya Varieties for Growth Parameters under Northern Dry Zone of Karnataka. Int.J.Curr.Microbiol.App.Sci. 6(9): 23982404. doi: https://doi.org/10.20546/ijcmas.2017.609.294 